\title{
THE DESTRUCTION OF BUDDHAS: DISSONANT HERITAGE, RELIGIOUS OR POLITICAL ICONOCLASM?
}

\author{
JALAL ATAI \\ Academy for Tourism, Breda University of Applied Sciences, Breda, The Netherlands
}

\begin{abstract}
This article attempts to explore the main impulses that might have led to the destruction of Buddha statues by Taliban in the Bamiyan Valley of Afghanistan. Drawing on existing literature, and anecdotal evidence, this article suggests that the main impulses that have led to destruction are rather linked to the overall political context of that time (i.e., political iconoclasm) rather than to pure Islamic iconoclasm or an explicit condition of disharmony in heritage (i.e., dissonant heritage). First, the Taliban did not consider the statues as "their" cultural heritage. The act of destruction, therefore, cannot be subscribed to the Afghan cultural dynamics but rather to the political-religious ideology imported by Taliban from outside of the country. Secondly, it seemed that Mullah Omar was viewing the statues as a revenue source at the beginning and as a political bargain chip at the end. In both circumstances, religion seems not to have played the main role. Lastly, the destruction seems a political iconoclasm - that is, a political exploitation, if not a direct political act. The Taliban and especially their external allies were very well aware of the consequences of the act of destruction. It seems implausible to suggest that there were no religion and/or culture in play when ordering the destruction of the statues. The latter is the least what this article aims for. However, to conclude that the destruction was solely triggered by theological and cultural factors might also be improbable. The author does not, in any way, attempt to rationalize the act of destruction, let alone justify the barbaric act.
\end{abstract}

Key words: Afghanistan; Bamiyan Buddhas; Dissonant heritage; Consonant heritage; Islamic iconoclasm; Political iconoclasm; Religious iconoclasm

Introduction

Afghanistan has been a cultural, ethnic, and linguistic crossroads throughout its history, thanks to its geographical position and ancient trade routes.
On the ancient Silk Road, about 250 km northwest of capital Kabul lies the Bamiyan Valley where two 6th century monumental statues of standing Buddha were carved into the side of a cliff. The statues survived earlier destruction attempts of Genghis Khan's army, Aurangzeb (the Mughal emperor), 
the Persian king Nader Afshar, and the Afghan king Abdur Rahman. The larger statue is called Salsal while the smaller (female) is called Shamama by locals and in Afghan literature (Reza'Husseini, 2012). The statues that were once hinted as visiting spot for international tourists even by the most zealot Muslim and reclusive leader of the Taliban, Mullah Omar, who later ordered their destruction, had been viewed as an important part of Afghan small tourism industry (Elias, 2007). In March 2001, the Taliban destroyed the two giant statues. The destruction, which was condemned by almost all nation-states and institutions, and was called a crime against culture and history further isolated the Taliban government, which was officially recognized only by Pakistan, Saudi Arabia, and the UAE.

The Taliban are groups of fundamentalist Sunni Muslim militants in Afghanistan and Pakistan. The Taliban held power in Afghanistan from 1996 to 2001. The Taliban are Afghan refugee children mostly born and/or grew up in Pakistan. They were educated in Saudi-financed madrassas in Pakistan that teach Wahhabism, a rigid form of Islam that is rooted in Saudi Arabia. The Pakistan's InterServices Intelligence (ISI) and military are widely alleged by international community and even people inside Pakistan for founding, supporting, and providing safe heavens to (Afghan) Taliban. To gain strategic depth, the ISI and the military used the Taliban to install a regime in Afghanistan that would be favorable to Pakistan, and give financial, logistical, and military support to the Taliban (Gardner, 2007; Giraldo, 2007; Hilali, 2005). Taliban are considered as a proxy serving the interests of the Pakistan ISI and the military, which favor a disintegrated Afghanistan. In addition, the influence of Al-Qaeda on Taliban's policy is also undeniable.

The discourse that followed the destruction of the statues seems to be lacking convincing evidence of the main factors that might have led to the destruction. Commonly, the destruction is perceived to be an act of religious iconoclasm while others have placed it in the context of "dissonant heritage."

There may be little doubt that Islamic iconoclasm (Centlivres, 2008; Francioni \& Lenzerini, 2003; Meskell, 2002; R. P. B. Singh, 2008) and Taliban's discordance with the statues (Ashworth \& Van der Aa, 2002; Hampton, 2005; Isaac \& Budryte-
Ausiejiene, 2015) might have contributed to the destruction. However, the anecdotal evidence, timing, and the way the destruction was carried out suggest that the main factors that might have contributed to Mullah Omar's decision are rather more complex and multidimensional.

Consistent with previous authors (ColwellChanthaphonh, 2003; Dupree, 2002; Flood, 2002; Gamboni, 2001; Janowski, 2011; Reza'Husseini, 2012) this article argues that the destruction was rather linked to the overall (immediate) political context than to pure Islamic iconoclasm or an explicit condition of disharmony in heritage.

This article contributes to the existing literature as follows. The findings reveal that any iconoclastic acts should be studied in an overall multidimensional context. Therefore, relating the destruction of the statues to solely theological and cultural impulses might be both premature and improbable.

To the knowledge of the author this is the first article that explores the impulses of the destruction where an extended amount of both existing national and international literature has been reviewed. In addition, this article distinguishes itself from existing related literature by using new national and local sources, both written and audio visual.

\section{Literature Review}

\section{Dissonant Heritage}

Heritage is considered dissonant when different groups, based on their beliefs, religion, culture, or political interest, attribute different stories to a certain object or landscape. The concept of "dissonant heritage" was pioneered by Tunbridge and Ashworth (1996). Dissonant heritage looks at the "ways in which the past can be used as a resource in present conflict situations” (p. 21). Tunbridge and Ashworth (1996) defined “ 'heritage dissonance’ as a condition of discordance or lack of agreement and consistency as to the meaning of heritage" (p. 21).

Chhabra (2012) claimd that "the existence of multiple ethnic communities” may result in dissonant point of views "which differ within and with the mainstream population” (p. 1702). Meskell (2002) defined dissonant heritage as "heritage that does not conform to prevailing norms or sites that are inherently disturbing” (p. 566). 
Dissonant heritage used in the context of this article is also rather analogous to negative heritage (Meskell, 2002), unwanted heritage, and unwanted past (Light, 2000). The term "consonant heritage," on the other hand, is used in this article as antonym to dissonant heritage. Consonant heritage, therefore, does conform to the norms, is not disturbing at all, is cherished and preserved. It should be noted that the term consonant heritage is neither a common concept nor a new one created by the author. The term is used here to only illustrate what could be considered as opposite to dissonant heritage.

\section{Iconoclasm}

Iconoclasm refers to an act of deliberately attacking, rejecting, or destroying (religious or cultural) images (Aston, 1988; Barnard, 1974; Gamboni, 1997; Martin, 1930) or visual representations. According to the World Heritage Encyclopedia, iconoclasm is "opposition to the veneration of inanimate representations, religious icons, and other symbols or monuments. In time, the word has also come to refer to the opposition to institutional inertia in one's own culture, usually for religious or political motives” (http://www.worldheritage.org/ article/WHEBN0000015085/Iconoclasm).

The first iconoclast on record is believed to be Moses (Sartwell, 2001). Despite the fact that competition over images can be traced back as far as Plato's dialogues (Eatough, 2010; Sartwell, 2001), the term iconoclasm is believed to be emerged in 8th century Christian Byzantine Empire (Eatough, 2010; Mercadal, 2015). Since then, the depredation of the Reformation and the events of the French Revolution could be referred to as Christian iconoclasm (Flood, 2002; van't Hof, 1998). In fact, the Dutch term "Beeldenstorm" that simply means "statues storm" refers to the wave of attacks that took place in the summer of 1566 (Historisch-nieuwsblad, 2005).

Oleg Graber (as cited in May \& Berlejung, 2012) claims that "the most obvious difference between Bazyntine and Islamic iconoclasm is that the former is usually spelled with a capital 'I' and the latter with a small 'I' "' (p. 8). However, according to May and Berlejung (2012), “The primary and most obvious difference between European iconoclasm, including that of Byzantium, and Near Eastern iconoclasm of all epochs is that the Byzantine and other Christians demolished images of their own god, not the god (or gods) of others” (p. 8).

According to Centlivres (2008), the revolutionary iconoclasm during the Great Cultural Revolution "destroyed Buddhist temples and images in Mongolia, Tibet and other places in Maoist China" (p, 2). In comparison to the latter, "nothing happened in Afghanistan” argued Centlivres (2008, p. 2).

The term iconoclasm used in this article is derived from the factors (i.e., cultural, theological, and political) causing, or motivations behind, the iconoclastic act rather the agent carrying out the act of destruction. Besides, this article distinguishes (pure) Islamic iconoclasm from political iconoclasm. Political iconoclasm in the context of this article includes all factors, including economic ones that have led to the destruction of the statues, except theological and cultural factors. This article, therefore, explicitly assumes Islam and politics as separate undertakings, which could be considered as limitation of this article.

\section{Islamic Iconoclasm}

Islamic iconoclasm in the context of this article is defined as act of attacking, rejecting, or destroying religious or cultural images, stemming solely from Islamic traditions, including Hadith. Therefore, the term Islamic iconoclasm as used in this article does not necessarily mean any iconoclastic act carried out by Muslims.

Islam, like other religions, has generally adopted a position opposed to certain visual and physical representations. This opposition, however, is not based on the Qur'an, but rather on various traditions derived from the Hadith (accounts of things said and done by the Prophet Mohammad) (Brubaker, 2009; Flood, 2002).

The Hadith includes statements such as, "Angels do not enter a house in which there are dogs or pictures" (Sahih-Al-Bukhari, 7.833, narrated by Abu Talha) or "The people who will receive the severest punishment from Allah will be the picture makers" (Al-Bukhari, 7834, narrated by Muslim) or "The makers of these pictures will be punished on the Day of Resurrection and it will be said to them, 
'Make alive what you have created" (Al-Bukhari, 7.840, narrated by Ayesha).

Muslim scholars are believed to be having some disagreements in interpretations of Hadiths and, as a consequence, the opposition to figural representation differs over time and varies significantly among different Islamic (sub)sects.

Allen (1988) wrote, "I prefer to term the Islamic phenomenon not iconoclasm, the rejection of images, but aniconism, the nonuse of images" (p. 3).

The very first and symbolic act of Islamic iconoclasm is believed to be the act of removing idols from the Ka'ba in Mecca by the Prophet Mohammad, and recent examples are perceived to be the destruction of Buddha status in Afghanistan and destruction of cultural heritage sites by Islamic State of Iraq and the Levant (ISIL) in Iraq, Syria, and Libya.

\section{Political Iconoclasm}

Political iconoclasm in the context of this article refers to any iconoclastic act carried out to achieve or manifest political objectives. Carrying out iconoclastic acts in a political context may also include achieving or manifesting other objectives such as economic and military, but it excludes any theological or cultural impulses.

According to W.J. Thomas Mitchell (as cited in May \& Berlejung, 2012), "Iconoclasm is always about politics" (p. 3). On the contrary May and Berlejung (2012) argued that "It is the motivation and the objective behind the act of destruction that makes an act iconoclastic, be this objective political, religious, magical, economic or an interlacing of all these” (p. 3). Besides, May and Berlejung (2012) doubt whether "iconoclasm is always about politics" will be "applicable to entire history of humankind” (p. 11).

According to James Noyes (as cited in Meinema, 2013), "the intended destruction of idols not only has religious, but also significant political effects, in the sense that it unites the adherents of the 'True God' under an often much more centralized 'True Government'.” Moreover, James Noyes contends that iconoclasm is "related to state-building, such as in the Protestant Reformation, the French Revolution, or the Islamic reformist movement of Shaikh
Muhammad bin Abdul-Wahhab, that united with the Najdi al-Saud family to lay the foundations for the modern Saudi Arabian state” (Meinema, 2013).

Reviewing Noyes (2013), Adam Deville (2014) writes that:

any outbreak of iconoclasm-whether in Calvinist Geneva, Wahhabist Afghanistan, revolutionary France, Nazi Germany, or the Balkans in the 1990s-is always the prelude to political reconfigurations and the emergence of a new state or new state actors. The theological arguments about icons and iconoclasm are in fact secondary in this book.

Deville (2014) also notes that in many cases it is difficult if not impossible to isolate one single cause of, or reason for, iconoclasm, but that it is often motivated by a tangle of theopolitical reasons.

George (2009) argued that, "Yet iconoclasm in Islamic communities, like iconoclasm in Western and largely Christian contexts, typically springs from crises and changes in politics and rule" (p. 591).

To manifest their political and military powers, agent(s) may search for publicity to expose their iconoclastic acts. The destruction of the statues is a modern examples of "publically staged, politicized acts of iconoclasm” (May \& Berlejung, 2012, p. 335). Furthermore, self-enrichment, among others, may also motivate iconoclasm. Indeed, Miles and Mclennan (2001) argued that "the most dangerous religion in the world, at least for art, remains the religion of the market."

\section{Discussion}

\section{Dissonant Heritage?}

The Bamyian Buddha statues were part of the cultural heritage of Afghanistan (Azmoone-melli, 2013; Elias, 2007), and Afghans had been trying to inscribe this and some other sites on the World Heritage list. Indeed, the Afghan government nominated the site to the World Heritage list in 1983 (Ashworth \& Van der Aa, 2002; The World Heritage Newsletter, 2001). Besides, the statues had been viewed as an important part of Afghanistan's small tourist industry and had been promoted as a symbol of Afghanistan's long heritage, appearing 
on postage stamps and state-produced cultural publications long before the Soviet invasion of Afghanistan in 1979 (Elias, 2007). An earlier attempt in 1983 by the then government to inscribe the site on the World Heritage list was deferred by the World Heritage Committee (The World Heritage Newsletter, 2001). While questioning the exclusion of the site from "the increasingly lengthy list of "World Heritage Sites' of UNESCO,” Ashworth and Van der Aa (2002, p. 448) posed the question whether the destruction would still have taken place if the valley had been inscribed as World Heritage site. Finally, the cultural landscape and archaeological remains of the valley was inscribed as a World Heritage site in 2003 - just 2 years after the destruction of the statues.

Afghanistan is a country with different ethnic communities, different Islamic denominations, and even different (sub)cultures. Therefore, the "condition of discordance or lack of agreement and consistency" (Tunbridge \& Ashworth, 1996, p. 21) regarding the statues is perceived to exist (Ashworth \& Van der Aa, 2002; Chhabra, 2012; Hampton, 2005; Meskell, 2002), which is bound to result in dissonant perspectives. However, despite significant differences in their attitudes towards the statues, an overwhelming majority of Afghans from different religions and different ethnical groups consider the statues as their heritage (Azmoone-melli, 2013; Elias, 2007). Therefore, the act of destruction cannot be simply subscribed to the Afghan cultural dynamics.

This article does not reject that "dissonant perspective of the Taliban" might have led to the destruction. However, based on the arguments put in order below, it might also be implausible to conclude that the destruction was a direct result of dissonant perspective.

i. The Taliban have never considered the statues or any other pre-Islamic artefacts as "their" heritage. Indeed, Mullah Omar was once quoted referring to the statues as "stones" (Coll, 2004, p.554), a term that is assigned to something meaningless or unimportant in Afghan terminology. Mullah Omar, therefore, did not consider or attribute any meanings, albeit positive or negative, or importance to the statues in the first place. Thus, for him, the statues were not disturbing, and, therefore, the "condition of discordance or lack of agreement and consistency" did not exist at all. Moreover, most Afghans do not consider Taliban being Afghans in the first place. Taliban were Afghan refugee children mostly born and grown up in Pakistan. They were educated in Saudi-financed madrassas in Pakistan that teach Wahhabism, a rigid form of Islam that is rooted in Saudi Arabia.

ii. Indeed, in July 1999 Mullah Omar issued a decree that said the statues shall not be destroyed but protected (Constable, 2001; Harding, 2001), and considered them as a potential major source of income for Afghanistan from international tourists (Harding, 2001). However, in February 2001 Mullah Omar issued a new decree calling for all ancient statues to be destroyed (ColwellChanthaphonh, 2003; Constable, 2001; Harding, 2001). The timing of the second decree, and the fact that it rejects the earlier edict, suggests that the destruction had more to do with the "Taliban's immediate relation to the international community" (Flood, 2002, p. 651) and/or with the "political context, to the progressive isolation of the Taliban" (Centlivres, 2008, p. 4) and less with dissonant perspectives of the Taliban.

iii. Some analysts suggest that the destruction was aimed at punishing and humiliating the Taliban's opposition groups, especially the local Shiite Hazara ethnic group (Constable, 2001; Rathje, 2001; Reza'Husseini, 2012; Vijh, 2007). These suggestions, which might be correct to a certain degree, have more to do with achieving political or military manifestations by the Taliban than with their view of dissonant heritage. As Flood (2002) suggested, "the intended audience for this communique was neither divine nor local but global: for all its recidivist rhetoric, this was a performance designed for the age of the Internet” (p. 651). It should be noted that almost all ordinary Afghans, regardless of their ethnical background, were shocked by the destruction of statues (Bucherer, n.d.; Constable, 2001). Paul Bucherer (Director of the Afghanistan Institute and Museum, Bibliotheca Afghanica in Switzerland.) disagreed that the destruction of the statues only harmed the Shia Hazara community in Afghanistan, and notes that, "This is simply not correct. I was in the Pashtun area of Mehtar Lam 
and I spoke to the Pashtuns about the destruction of the Buddhas in Bamiyan and tears came to their eyes and they started to cry about the loss of this national cultural heritage" (Bucherer, n.d.). It seems unlikely that the statue were destroyed in order to get back at the Hazaras, because the monuments held no ritual significance for them. Besides, the Taliban have rarely resorted to symbolic actions when more direct ones were available.

The statues were meaningless- "the stones" to the Taliban. For them, therefore, they were not heritage in the first place, let alone dissonant heritage or consonant heritage. The act of destruction, therefore, cannot be subscribe to the Afghan cultural dynamics, but rather to the political-religious ideology of the Taliban.

\section{Islamic Iconoclasm?}

Islamic iconoclasm in the context of this article is defined as act of attacking, rejecting, or destroying religious or cultural images, stemming solely from Islamic traditions, including Hadith. It is worth mentioning that this article does not, in any way, suggest that Islamic interpretations have played no role in the destruction of the statues. Indeed, the one issuing the decree of destruction and the very individuals carrying out the act of destruction were all zealot Muslims. However, based on the arguments put in order below, it seems implausible to conclude that the destruction was a direct result of Islamic iconoclasm.

i. The shift from protection to destruction of the statues by the Taliban is a phenomenon that needs to be further analyzed. The evidence shows that Taliban are very uncompromising as far as the implementation of Sharia or any Islamic decree is concerned. In his first decree, issued in July 1999, Mullah Omar reasoned the nonexistence of worshippers and the future economic benefits from international visitors to protect the statues (Bucherer, n.d.; Burke, 2001; Harding, 2001). This inconsistency (i.e., from protection to a sudden destruction) seems very odd.

ii. Because the statues were belonging to a preIslamic era, and there were no Buddhists left in Afghanistan, the Afghans and even the Taliban did not perceived them as threat to Islam. Even the great Iconoclast Sultan Mahmud of Ghazna had spared the statues while destroying the Shiva temple at Somnath, Gujrat, in 1025 CE (Elias, 2007). The reason might be simplethe Bamiyan statues were not worshipped. It is also improbable to assume that despite a short distance between Ghazna and Bamyian, Sultan Mahmud of Ghazna was unaware of the existence of the statues. So it was clear, even to Mullah Omar, that the statues had no religious function at all. Therefore, destroying them would also serve no religious purposes. Coll (2004) wrote that when Mullah Omar was asked, "When they have spared these statues for fifteen hundred years, all these Muslims who have passed by them, how are you a different Muslim from them,” Mullah Omar perceivably replied "Maybe they did not have the technology to destroy them” (p. 554). This postdestruction remark seems an irrational answer to justify the action already taken and the consequent damage already done rather than technology being the main factor in destruction. The Taliban had the same technology from the outset, and, if they wanted to destroy the statues, they could do so using the same technology in 1998.

iii. The very question that needs an answer is what made Mullah Omar, and especially after almost 2 years, to change his mind from protection to destruction. If the theological issues were at stake, taking Taliban's very strict and uncompromising view of Islam into account, Mullah Omar would have not hesitated to destroy the statues at the outset rather than protecting them. Therefore, there should have been more reasons, next to the theological ones, to just do the opposite. The almost 3-year time gap between the capture of the Bamiyan Valley in 1998 and the destruction in 2001 is an important point of discussion. The question that arises is why Mullah Omar waited so long to destroy the statues when he had all the means to destroy them even in 1998. The answer may lie in the overall (immediate) political context in which the Taliban were in at the beginning of 2001 (i.e., just prior to the destruction).

iv. Elias (2007) argued that the Hijri calendar has played a role in the proceedings. According to Elias (2007), the timing of the second decree 
ordering destruction of the statues might have been influenced by the sacred period of Hajj pilgrimage and Eid al-adha. However, Hajj pilgrimage and Eid al-adha are reoccurring events that take place very year, thus not only in 2001. Therefore, if these events would have played a role, they would surely have done so also in the previous years.

It seemed that Mullah Omar was viewing the statues as a revenue source at the beginning and as a political bargain chip at the end. In both circumstances, religion seems not to have played the main role.

\section{Political Iconoclasm?}

Political iconoclasm in the context of this article refers to any iconoclastic act carried out to achieve or manifest political objectives. Carrying out an iconoclastic act in a political context may also include achieving or manifesting other objectives such as economic and military, but it excludes any theological or cultural impulses. As far as the underlying impulses that have led to the destruction are concerned, this article explicitly assumes Islam and politics being separate undertakings rather than a joint enterprise.

The evidence, timing, and the arguments put in order below suggest that politics, albeit irrational, might have been the main, if not the only, impulse for Mullah Omar to order the destruction of the statues.

i. The Taliban were completely isolated on the international scene (Frei, 2005). Officially they were only recognized by Pakistan, Saudi Arabia, and UAE. Internationally, both Pakistan and Saudi Arabia are accused of direct military and financial assistance to the Taliban, respectively. The Taliban regime was facing increased UN sanctions, after the regimes' rejection to extradite terrorist leader Osama bin Laden (Romey, 2001). Dario Gamboni relates the decision to destroy the statues to "Taliban's frustration at failing to achieve international recognition and to the economic sanctions imposed upon the country by the UN because of its alleged links to Islamic terrorism” (Gamboni, 2001). According to some commentators Mullah Omar had spared the statues for several years in the hope of improving relations with the West. However, the increased pressure convinced him that he had nothing left to lose. "His response to the rest of the world: If you want the monuments to survive, then recognize us as we are" (The Arts Journal, 2001). The decision to destroy the statues is therefore perceived to be a defiant reaction to international community and/or international sanctions (Burke, 2001; Carraso, 2015; Harding, 2001; Romey, 2001; Saikal \& Ramesh, 2001; K. Singh, n.d.; R. P. B. Singh, 2008). For the Taliban it was setting their political agenda (Frei, 2005).

ii. The Taliban's isolated regime was attempting to find ways to draw global attention. However, it seemed that the regime was failing in almost all fronts. Some commentators suggest that the destruction was carried out to attract global attention or international publicity (ColwellChanthaphonh, 2003; Flood, 2002; Francioni \& Lenzerini, 2003; Janowski, 2011; Meskell, 2002; Semple, 2011) which despite being an "irreparable loss for all mankind" seemed successful to a certain degree. According to Semple, Taliban "had found a brilliant source of international publicity where it could strike a successful pose of defiance" (Semple, 2011).

iii. The influence of Al-Qaeda, Pakistan's ISI, and other external players on Taliban's policy is undeniable. Taliban are considered as a proxy serving the interests of certain elements inside Pakistan that may favor a disintegrated Afghanistan. A united Afghanistan, culturally or otherwise, is falsely perceived as threat to Pakistan by certain elements inside Pakistan military and security services. As a result, some commentators suggest that the destruction was influenced or inspired by Al-Qaida and/or Pakistani (ISI) elements (Behzad, 2010; Burke, 2001; Faizi, 2010; Flood, 2002; Frei, 2005; Janowski, 2011; Muzhda, 2005; Rathje, 2001; Semple, 2011; K. Singh, n.d.; Vijh, 2007). Some commentators even suggest that destruction itself might have been carried out by Al-Qaeda and Pakistani elements (Bucherer, n.d.; Frei, 2005; Semple, 2011). Therefore, it was not a surprise that Pakistan was the only country, if not the whole country, where the destruction was celebrated or received as good news by certain 
elements (Elias, 2007; Reuters, 2001; K. Singh, n.d.).

iv. Some other commentators consider the destruction as a response of the Taliban to the favoritism of West towards the protection of the statue over the human sufferings in Afghanistan (Centlivres, 2008; Crossette, 2001; Gamboni, 1997; May \& Berlejung, 2012).

v. According to some sources the destruction was a response (of certain Pakistani elements) to the destruction of Babri Mosque in India by Hindu extremists (Bernbeck, 2013; Elias, 2007).

vi. Others perceive the destruction a way to punish and humiliate the Taliban's opposition groups, especially the local Shiite Hazara ethnic group (Constable, 2001; Rathje, 2001; Reza'Husseini, 2012; Vijh, 2007)

vii. Lastly, some commentators suggest that the order to destroy all idols, including the statues, were given as a part of a large scale smuggling of artefacts, especially to Pakistan (Gamboni, 2001; Miles \& McLennan, 2001; Naderi, 2012). As Gambani (2001) wrote, "According to some commentators, the order to destroy idols served to cover up the widespread smuggling of valuable pre-Islamic artefacts out of the country, especially toward Pakistan-smuggling that could only be carried out with the connivance of Taliban authorities.”

The destruction seems a political iconoclasmthat is, a political exploitation, if not a direct political act. The Taliban and especially their external allies were very well aware of the consequences of the act of destruction. As Janowski (2011) put it convincingly, "Given the attendant costs, the question of the Taliban's motivation is an interesting one, and it seems both too easy and even quite misguided to dismiss the Taliban as unthinking zealots” (p. 58).

\section{Conclusion}

This article does not attempt to rationalize the barbaric act of the destruction of Buddha statues in Bamiyan Vally. It neither attempts to ignore the significance of theological and cultural impulses that may have led to the destruction by the Taliban. However, it suggests that politics rather than religion and culture might have been the main, if not the only, impulse for the Taliban to destroy the statues and other idols in Afghanistan.

As far the heritage, the Taliban have never considered the statues as their past, neither good nor bad. For them, the statues were meaningless objects that may serve their potential political or economic objectives. The act of destruction, therefore, cannot be subscribed to the Afghan cultural dynamics but rather to the political-religious ideology of the Taliban.

The Taliban were not anymore the zealot Muslims who only knew religion. They were learning politics, thought and facilitated by Al-Qaeda and ISI. The Taliban understood that what they were destroying were not religious icons (Flood, 2002). They were exploiting politics (Dupree, 2002), albeit irrational politics (Vijh, 2007).

The explicit assumption of Islam, politics and culture being separate undertakings is rather an inconsistency with some existing literature and a limitation of the current article.

Further research on the impulses that may have led to the destruction is needed, and any explicit conclusion relating to the destruction to one single impulse might be both premature and implausible. Information from the "surrendered" insiders such as Mullah Abdul Salam Zaeef, Taliban's ambassador to Pakistan, and Wakil Ahmad Muttawakil, Taliban's foreign minister, might be helpful to get deeper insights into the motivations and impulses of the destruction.

\section{Acknowledgments}

I would like to thank Rami Isaac, Vincent Platenkamp, and Brian Wheeller for their guidance and the anonymous reviewer for critical comments on early version of the article.

\section{References}

Allen, T. (1988). Five essays on Islamic art. Sebastopol, CA: Solipsist Press.

Ashworth, G. J., \& Van der Aa, B. J. (2002). Bamyan: Whose heritage was it and what should we do about it? Current Issues in Tourism, 5(5), 447-457.

Aston, M. (1988). England's iconoclasts: Vol. 1: Laws against images. Oxford, UK: Clarendon Press.

Azmoone-melli. (2013).

. Retrieved from http://my.azmoone-melli. $\operatorname{com} / \mathrm{go} / 2782$ 
Barfield, T. (2001). Idol Threats. Retrieved from http://www. trincoll.edu/depts/csrpl/rinvol4no2/Idol\%20Threats.htm

Barnard, L. W. (1974). The Graeco-Roman and Oriental Background of the iconoclastic controversy.[Mit Kt.Skizze.] (Vol. 5). Boston, MA: Brill.

Behzad, N. (2010, February 28).

Retrieved from http://janbehzad.blogspot. $\underline{\text { nl/2010/02/blog-post_28.html }}$

Bernbeck, R. (2013). Heritage void and the void as heritage. Archaeologies, 9(3), 526-545.

Brubaker, L. (2009). Representation c. 800: Arab, Byzantine, Carolingian. Transactions of the Royal Historical Society (Sixth Series), 19, 37-55.

Bucherer, P. (n.d.) How can Afghanistan's cultural heritage be preserved?/Interviewer: N. Shaikh. The Asia Society. Retrieved from https://asiasociety.org/how-canafghanistans-cultural-heritage-be-preserved

Burke, J. (2001). Diary. London Review of Books, 23(6), 38-39. Retrieved from http://www.lrb.co.uk/v23/n06/ jason-burke/diary

Carraso, S. (2015). Controversy over Bamiyan Buddhas. Retrieved from http://www.newhistorian.com/controversybamiyan-buddhas/2770/

Centlivres, P. (2008). The controversy over the Buddhas of Bamiyan. South Asia Multidisciplinary Academic Journal. Retrieved from https://journals.openedition.org/ samaj/992

Chhabra, D. (2012). A present-centered dissonant heritage management model. Annals of Tourism Research, 39(3), 1701-1705.

Coll, S. (2004). Ghost wars: The secret history of the CIA, Afghanistan, and bin Laden, from the Soviet Invasion to September 10, 2001. New York, NY: Penguin.

Colwell-Chanthaphonh, C. (2003). Dismembering/disremembering the Buddhas Renderings on the Internet during the Afghan purge of the past. Journal of Social Archaeology, 3(1), 75-98.

Constable, P. (2001, March 20). Buddhas' rubble marks a turn for Taliban. Washington Post. Retrieved from https:// www.washingtonpost.com/archive/politics/2001/03/20/ buddhas-rubble-marks-a-turn-for-taliban/80ee5d4be7d1-4955-99b1-717973a60583/

Crossette, B. (2001, March 19). Taliban explains Buddha demolition. New York Times. Retrieved from https:// www.nytimes.com/2001/03/19/world/taliban-explainsbuddha-demolition.html

Deville, A. (2015, February 4). Eastern Christian books. Retrieved from http://easternchristianbooks.blogspot. com/2014/01/the-politics-of-iconoclasm-and.html

Dupree, N. H. (2002). Cultural heritage and national identity in Afghanistan. Third World Quarterly, 23(5), 977-989.

Elias, J. J. (2007). (Un) making Idolatry: From Mecca to Bamiyan. Future Anterior: Journal of Historic Preservation, History, Theory, and Criticism, 12-29.

Faizi, E. K. (2010).

. Retrieved from http://www.kabulnath.de/Salae_ Shashoum/Shoumare_116/EmeelKhan\%20Faizi.html
Flood, F. B. (2002). Between cult and culture: Bamiyan, Islamic iconoclasm, and the museum. The Art Bulletin, 84(4), 641-659.

Francioni, F., \& Lenzerini, F. (2003). The destruction of the Buddhas of Bamiyan and international law. European Journal of International Law, 14(4), 619-651.

Frei, C., Director (Writer). (2005). The Giant Buddhas. Documentary, 35mm, 95 Min.

Gamboni, D. (1997). The destruction of art. Iconoclasm and vandalism since the French Revolution. London, UK: Reaktion Books Ltd.

Gamboni, D. (2001). World heritage: Shield or target? Retrieved from http://www.getty.edu/conservation/pub lications_resources/newsletters/16_2/feature.html

Gardner, H. (2017). American global strategy and the 'war on Terrorism'. New York, NY: Routledge.

George, K. M. (2009). Ethics, iconoclasm, and Qur'anic art in Indonesia. Cultural Anthropology, 24(4), 589-621.

Giraldo, J. K., \& Trinkunas, H. A. (2007). Terrorism financing and state responses: A comparative perspective. Palo Alto, CA: Stanford University Press.

Hampton, M. P. (2005). Heritage, local communities and economic development. Annals of Tourism Research, 32(3), 735-759.

Harding, L. (2001, March 2). How the Buddha got his wounds. The Guardian. Retrieved from http://www.theguardian. com/books/2001/mar/03/books.guardianreview2

Hilali, A. Z. (2005). US-Pakistan relationship: Soviet invasion of Afghanistan. Hampshire, UK: Ashgate.

Historisch-nieuwsblad. (2005). De beeldenstorm in de Nederlanden. Retrieved from https://www.historischnieuwsblad. nl/nl/artikel/47898/de-beeldenstorm-in-de-nederlanden. html

Isaac, R. K., \& Budryte-Ausiejiene, L. (2015). Interpreting the emotions of visitors: A study of visitor comment books at the Grūtas Park Museum, Lithuania. Scandinavian Journal of Hospitality and Tourism, 15(4), 400-424.

Janowski, J. (2011). Bringing back Bamiyan’s Buddhas. Journal of Applied Philosophy, 28(1), 44-64.

Light, D. (2000). An unwanted past: Contemporary tourism and the heritage of communism in Romania. International Journal of Heritage Studies, 6(2), 145-160.

Martin, E. J. (1930). A history of the iconoclastic controversy (Vol. 2). New York, NY: AMS Press.

May, N. N., \& Berlejung, A. (2012). Iconoclasm and text destruction in the ancient Near East and beyond. Chicago, IL: Oriental Institute of the University of Chicago.

Meinema, E. (2013). Dr James Noyes and the Politics of Iconoclasm. Retrieved from https://www.rug.nl/ research/centre-for-religious-studies/religion-conflictglobalization/blog/dr-james-noyes-and-the-politics-oficonoclasm-16-10-2013

Meskell, L. (2002). Negative heritage and past mastering in archaeology. Anthropological Quarterly, 75(3), 557-574. 
Miles, \& McLennan. (2001). The Most Dangerous Religion (Hint: It's not Islam). Retrieved from http://www. artsjournal.com/artswatch/aw-taliban.htm

Muzhda, W. (2005). Interviewer: S. Saidi. BBC Persian.

Naderi, P. (2012, 11 Mar 2012). /Interviewer: M. Pedram. Deutsche Welle.

Noyes, J. (2013). The politics of iconoclasm: Religion, violence and the culture of image-breaking in Christianity and Islam (Vol. 33). London, UK: IB Tauris.

Rathje, W. L. (2001, March 22). Why the Taliban are destroying Buddhas. USA Today. Retrieved from http:// usatoday30.usatoday.com/news/science/archaeology/ 2001-03-22-afghan-buddhas.htm

Reuters. (2001, March 6). Taliban Rules Out Compromise on Buddha Statues. Reuters. Retrieved from http://www. atour.com/news/international/20010306a.html

Reza'Husseini, S. (2012). Destruction of Bamiyan buddhas Taliban iconoclasm and Hazara response. Himalayan and Central Asian Studies, 16(2), 15.

Romey, K. M. (2001). Cultural terrorism. A publication of the Archaeological Institute of America, 54 Number 3. Retrieved from http://archive.archaeology.org/0105/news briefs/afghan.html

Saikal, A., \& Ramesh, T. (2001). Vandalism in Afghanistan and no one to stop it. The New York Times. Retrieved from http://www.nytimes.com/2001/03/06/opinion/06ihtedram.t.html
Sartwell, C. (2001, March 10). From Moses to the Taliban. The Washington Post. Retrieved from https://www.washingtonpost.com/archive/opinions/2001/03/10/from-mosesto-the-taliban/7f826037-b3db-4206-a036-20643c754d83/

Semple, M. (2011). Why the Buddhas of Bamian were destroyed. Retrieved from https://www.afghanistan-analysts.org/ guest-blog-why-the-buddhas-of-bamian-were-destroyed/

Singh, K. (n.d.). Museums, heritage, culture. Into the conflict zone. Retrieved from https://www.ahk.nl/media/rwa/ docs/2015KavitaSingh_MuseumsHeritageCulture.pdf

Singh, R. P. B. (2008). The contestation of heritage: The enduring importance of religion. In B. Graham \& P. Howard (Eds.), The Ashgate research companion to heritage and identity (pp. 125-142). Farnham, UK: Ashgate Publishing.

The Arts Journal. (2001, March 13). Attention Getter. Newsweek (MSNBC). Retrieved from http://www.artsjournal. com/issues/Taliban.htm

The World Heritage Newsletter. (2001, May-June). Editorial. Retrieved from https://whc.unesco.org/document/3063

Tunbridge, J. E., \& Ashworth, G. J. (1996). Dissonant heritage: The management of the past as a resource in conflict. Chichester, UK: John Wiley \& Sons.

van't Hof, C. (1998). Vandalen of iconoclasten? De Kunstvernielers van Dario Gamboni. Psychologie en Maatschappij, 22(1), 101-103.

Vijh, S. (2007). Monuments of Destruction - Islamic clergy disagree with Taliban government over destroyed statues. Retrieved from http://suevijh.blogspot.com/ 